

\title{
An Unpublished Letter from James Mill to Jean-Baptiste Say
}

Victor Bianchini, Nicolas Rieucau

\section{To cite this version:}

Victor Bianchini, Nicolas Rieucau. An Unpublished Letter from James Mill to Jean-Baptiste Say. History of Political Economy, 2014, 46 (2), pp.333 - 338. 10.1215/00182702-2647531 . hal-01615078

\section{HAL Id: hal-01615078 https://hal.science/hal-01615078}

Submitted on 11 Oct 2017

HAL is a multi-disciplinary open access archive for the deposit and dissemination of scientific research documents, whether they are published or not. The documents may come from teaching and research institutions in France or abroad, or from public or private research centers.
L'archive ouverte pluridisciplinaire HAL, est destinée au dépôt et à la diffusion de documents scientifiques de niveau recherche, publiés ou non, émanant des établissements d'enseignement et de recherche français ou étrangers, des laboratoires publics ou privés. 


\title{
An Unpublished Letter from James Mill to Jean-Baptiste Say
}

\author{
Victor Bianchini ${ }^{*} \&$ Nicolas Rieucau ${ }^{* *}$
}

Forty years ago, on the occasion of the publication of two unpublished letters from J. Mill to J.-B. Say, A. Heertje underlined that "although Say was a friend and correspondent of James Mill, letters from Mill to Say seldom turn up" ${ }^{\prime 1}$. Dated the $25^{\text {th }}$ of February 1817 and the $28^{\text {th }}$ of May 1825, the letters published by A. Heertje were purchased from a Parisian bookshop and, outside the private collections of autographs, to our knowledge, no correspondence between J. Mill and J.-B. Say had been hitherto reported. Thanks to the development of electronic catalogues, it is now possible to find other traces of the epistolary relationship between J. Mill and J.-B. Say. For example, the online catalogue of manuscripts maintained by the Bibliothèque nationale de France turns up two additional letters ${ }^{2}$.

In the future, one can assume that the progressive enrichment of electronic research tools ${ }^{3}$ will permit to multiply these types of discovery. Still catalogued in paper format, important manuscript databases rest effectively unsearchable in electronic format. Thus is the case for the collection of professor L. Darmstaedter ${ }^{4}$, kept in the Staatsbibliothek zu Berlin where one can find the letter from J. Mill to J.-B. Say dated June 6,1821 that we hereinafter publish ${ }^{5}$.

\footnotetext{
*PHARE (Université Paris 1). Email : victor.bianchini@univ-paris1.fr.

** LED (Université Paris 8). Email: nicolas.rieucau@univ-paris8.fr.

${ }^{1}$ A. Heertje [1971, p. 415].

2 One, unpublished, dates from March 20, 1815 (n. a. fr. 26252, f. 264). The other, from May 26, 1821 (n. a. fr. 26252, f. 262-263), is published in A. Heertje \& E. Schoorl [1972, p. 10-11]. Of course, at the time of publication, they did not have access to the online catalogue of the Bibliothèque nationale de France.

${ }^{3}$ About these instruments, see N. Rieucau [2009, p. 19-20].

${ }^{4}$ One will find in the Deutsche biographische Enzyklopädie [vol. 2 (2005), p. 499-500] a notice devoted to this German chemist and great collector of autographs born in Mannheim in 1846, died in Berlin in 1927.

${ }^{5}$ This letter is conserved under the shelf mark $2 \mathrm{~g} 1804$ (1). The exact date of its acquisition by $\mathrm{L}$. Darmstaedter is unknown. No catalog sale can be found in the folder containing this letter. The only indication that we dispose of concerning its date of acquisition took place, at the latest, at the end of 1907, the year L. Darmstaedter bequeathed his collection and published the inventory - see L. Darmstaedter
} 
This specificity could merit, by itself, such a publication; the examination of the letter's content more justifies it. Far from being anecdotal, this letter enlightens us in several ways with regards to the dissemination of the works of J. Mill and J.-B. Say, and J. S. Mill's stay in the home of J.-B. Say in France. After having situated the letter within the body of epistolary relations between the two men, this paper will then proceed to present these two aspects.

In the correspondence of J. Mill, except by omission on our part ${ }^{6}$, the name J.-B. Say appeared for the first time in a letter addressed to Ricardo, dated the $14^{\text {th }}$ of November $1814^{7}$. J. Mill, who profited of J.-B. Say's arrival in Great Britain ${ }^{8}$, solicited F. Place $^{9}$ in order to both meet the author of Traité $d^{\prime}$ economie politique and put him in contact with D. Ricardo and J. Bentham. J. Mill had thus not yet corresponded with J.-B. Say before this date: If he had, he would not have resort to a third person to meet him. This meeting took place, as attested by J. Mill's letter addressed to J.-B. Say the $20^{\text {th }}$ of

[1909]. The L. Darmstaedter collection includes several thousand autographs coming particularly from the history of sciences. Other than the J. Mill letter, this collection also contains other unpublished letters from economists. These include, for example, three letters from Turgot [2 | 1761 (2)], two letters from Ricardo [2 g 1820 (2)], three letters from Sismondi [2 g 1836 (3)] and six letters from J.-B. Say [2 g 1815 (2)]. The letters from Ricardo, J.-B. Say and Sismondi will respectively be published, in a few years, by C. Depoortère from the Université Paris 8, the team TRIANGLE from the Université Lyon II in the CEuvres complètes of J.-B. Say and the Walras-Pareto Centre of Lausanne within the CEuvres économiques complètes of Sismondi.

${ }^{6}$ The publication of the complete works of J. Mill has not yet seen the light of day. In addition to the previously cited references - supra p. 1, this correspondence has appeared until now in a very patchy manner, notably in The Works and Correspondence of David Ricardo (vol. 6-9), The Works of Jeremy Bentham (vol. $10 \& 12$ ) and in the bibliography of J. Mill performed by A. Bain [1882].

${ }^{7}$ The Works and Correspondence of David Ricardo, Vol. VI, p. 156-159.

${ }^{8}$ Indeed, J.-B. Say was attributed a mission to visit Great Britain by the French government from September to December 1814 in order to study the economic state of the country an bring back useful information. Upon returning from this trip, he published De l'Angleterre et des Anglais [1815]. J.-B. Say's trip to Great Britain was made possible by the signature of the first Treaty of peace of Paris the $30^{\text {th }}$ of May 1814 following the defeat of Napoléon $1^{\text {st }}$. This was not the first time that J.-B. Say travelled to Great Britain. He made the journey, notably, at the age of 19 and stayed for two years, with his brother Horace, to round off his commercial education and observe the industrial development of the country. On this subject, see E. Teilhac [1927, p. 7].

${ }^{9}$ F. Place [1771-1854] was a British social reformer. The author of Illustrations and Proofs of the Principle of Population [1822] was an important political ally of J. Mill [A. Bain 1882, p. 77] and corresponded regularly with J.-B. Say. From 1825, the correspondence between F. Place and J.-B. Say indicated that he was given the task of translating, from French to English, three of J.-B. Say's critical texts of the Ricardian school [J.P. Potier (2009), pp. 559-560]. 
March $1815^{10}$. The fact that J. Mill communicated to him, in post-scriptum ${ }^{11}$, his postal address in London seems to indicate that this letter marked the beginning of their epistolary relationship. This relationship spanned at least a dozen years. Indeed, the latest letter known to this day is dated the $28^{\text {th }}$ of May $1825^{12}$. The letter published in this article was written four years before and directly follows another letter ${ }^{13}$ addressed to J.-B. Say the $26^{\text {th }}$ of May 1821.

A substantial part of the letter that is reviewed here is devoted to the dissemination of the work of J.-B. Say. This man placed much emphasis on the importance of the international reception of this writings. Numerous translations of his Traité d'economie politique, in which he made important collaborative efforts, bear testament to his concern ${ }^{14}$. Despite the efforts of J.-B. Say, his Traité was poorly received in Great Britain ${ }^{15}$. In this country, only one translation - C. R. Prinsep's fourth edition ${ }^{16}$ dating from 1821 - saw the light of day. In April 1821, C. R. Prinsep sent his translation to J.-B. Say ${ }^{17}$. Nevertheless, J.-B. Say subsequently informed him that he was not satisfied with this translation for two reasons: on the one hand, it did not incorporate the "Discours préliminaire" and the "Epitomé" of his Traité ${ }^{18}$ and, on the other hand, J.-B. Say was not convinced by the translator's critical and explanatory notes, because they were close to Ricardian ideas on the subject of value ${ }^{19}$. J.-B. Say, who desired to make known his critical opinion of this translation, endeavored to publish a response to C. R. Prinsep. J.-P. Potier [2009, p. 156] recently remarked that J.B. Say had solicited J. Mill to publish his response to the translator in Great Britain. The

${ }^{10}$ J. Mill to J.-B. Say, Bibliothèque nationale de France, n. a. fr. 26252, f. 264 r.

${ }^{11}$ Ibid

${ }^{12}$ In A. Heertje [1971, p. 417-418].

${ }^{13}$ J. Mill to J.-B. Say [1821, p. 10-11], published in A. Heertje \& E. Schoorl [1972, p. 10-11].

${ }^{14}$ On this point, see J. P. Potier [2009].

${ }^{15}$ However, the critical reception of the Traité was positive in the United States. On this question see ibid., p. 132

${ }^{16}$ Originally trained as a lawyer before becoming an economist, C. R. Prinsep [1798-1864] published, in 1816, A Letter of the Earl of Liverpool, on the Cause of the Present Distress of the Country, and the Efficacy of Reducing the Standard of our Silver Currency, and, in 1818, An Essay on Money. For more information on C. R. Prinsep, see D. Ashbury [2004] and J. P. Potier [2009, p. 152].

${ }^{17}$ See $C$. R. Prinsep à J.-B. Say [16 April 1821], Bibliothèque nationale de France, n. a. fr. 26252, f. 331-333.

${ }^{18}$ J.-B. Say à C. R. Prinsep [May 1821], p. 140-141.

${ }^{19}$ Ibid., p. 142-145. 
letter reviewed here constitutes material proof of his intentions. Indeed, after J. Mill affirmed that J.-B. Say's response seemed "admirable; the matter most important, \& the manner at once pointed \& delicate", he said he had no doubt "about the propriety of publishing it" in one of his "more respectable journals" ${ }^{20}$ and that he "shall endeavor to make some of them notice it as soon as published". However, this letter was only ever published after the death of J.-B. Say in 1833 by his own son-in-law, Charles Comte [1782 - 1837] in Mélanges et correspondances d'économie politique. It is difficult to know the reason or reasons for which J. Mill did not publish the letter through his channels. But one can imagine that J. Mill sang the praises of Say's letter, that he further proposed to publish it, out of simple courtesy towards someone that had hospitably welcomed his son in his home in Paris. Moreover, even if J. Mill and J.-B. Say shared certain ideas, notably on the hegemony of Napoléon ${ }^{21}$ or the colonization of India by Great Britain ${ }^{22}$, the former did not have the best opinion of the economic ideas of the latter. Indeed, even though J. Mill had, in 1805, welcomed with praise the first edition of J.-B. Say's treatise [1803], pointing out in particular the law according to which supply cannot exceed demand ${ }^{23}$ and the triptych order of subject matter's exposition ${ }^{24}-$ laws of production, distribution, and the consumption of wealth; even though one can find this law in his Commerce Defended [1808, pp. 37-38] and this order of exposition - with several modifications - in his Elements of Political Economy [1821] ${ }^{25}$, it doesn't any less stand that he did not seem, from 1818, to be convinced by the ideas of J.-B. Say on the

\footnotetext{
${ }^{20} \mathrm{~J}$. Mill was thinking perhaps of one of the reviews in which he had already written, among which figure notably The Edinburgh Review, The Westminster Review and The London Review. The integrality of these reviews was indexed by D. Winch [1966, p. 328-331].

${ }^{21} \mathrm{~J}$. Mill and J.-B. Say had, in fact, both vehemently criticized this hegemony. On J. Mill's engagement against the supremacy of Napoléon, see R. Yasukawa [1991]. As for J.-B. Say, see J. Wolff [2005].

${ }^{22}$ J.-B. Say [1824, p. 9] was inspired, on this issue, by Mill's History of British India [1817] that he even described as "excellent[e]"

${ }^{23}$ J. Mill [1805, p. 419-421]. See also D. Winch [1966, p. 29].

${ }^{24}$ J. Mill [1805, p. 415-416].

${ }^{25}$ For as much as we know, E Halévy [1901-1904, vol. II, p. 147] is the first to have brought attention to this latter similarity. Nonetheless, the question of value and exchanges constitutes a chapter to itself in the Elements, while it appears, in the Traité, on the one hand, in book I on the production of wealth and, on the other hand, in book II on the distribution of wealth.
} 
question of value and distribution. On this point, J. Mill was a convinced Ricardian ${ }^{26}$. His work shows his proximity with D. Ricardo - and, hence, his distance with J.-B. Say when, for example, he underlined, in his Elements of Political Economy, the mechanism of differential rent ${ }^{27}$, the inverse relation between salary and profit ${ }^{28}$, or the manner in which value is determined ${ }^{29}$. But even more palpably, J. Mill's Ricardianism makes itself known in his correspondence, directly contrary to J.-B. Say's ideas ${ }^{30}$. If a "duty" of courtesy thus seems to motivate J. Mill when he claimed to appreciate J.-B. Say's letter to C. R. Prinsep and proposed to publish it, it appears that he was himself disposed to sending his own writing projects to J.-B. Say. The letter that we publish here reveals, in fact, that J. Mill sent him two texts, "Government" and "Jurisprudence" ${ }^{31}$, destined for the same publication ${ }^{32}$ and presented as an "outline of the business legislation". The first of these texts was judged favorably by J.-B. Say: "The praise you bestowed upon the article Government ${ }^{33}$, has emboldened me to beg your acceptance of another article (Jurisprudence) which I have prepared for the same publication". Further, J. Mill informed him that he will soon publish what he called a "school book of political

\footnotetext{
${ }^{26}$ For a recent opinion on the divergences between Ricardo and J.-B. Say on the question of value and distribution, see C. Gehrke \& H. D. Kurz [2001].

${ }^{27}$ J. Mill [1821, p. 29-40].

${ }^{28}$ Ibid., p. 72-86.

${ }^{29}$ lbid., p. 87-90.

${ }^{30}$ See notably J. Mill to Ricardo [24 December 1818, p. 297] and J. Mill to Ricardo [14 January 1819, p. 10].

${ }^{31}$ As he had already announced in his letter dated the 26th of May 1821, see J. Mill to J.-B. Say, Bibliothèque nationale de France, n. a. fr. 26252, f. 262. One can also make reference to A. Heertje \& E. Schoorl [1972, p. 10-11].

32 "Jurisprudence" and "Government" were finally published several years later, in 1824, in The Supplement to the $4^{\text {th }}, 5^{\text {th }}$, and $6^{\text {th }}$ Editions of the Encyclopaedia Britannica, Edinburg, 6 volumes. As D. Winch [1966, p. 328] remarked, these "supplements" appeared already in "half-volumes" between 1815 and 1824 and they were also separately published at the beginning of the 1820 s.

${ }^{33}$ The praise of the article "Government" does not seem anecdotal. As we have indicated - see supra, p. 4, n. 22, J.-B. Say [1840, vol. I, p. 50] cited and took inspiration, several years later, from a passage from the History of British India that echoes in some ways one of the ideas of Mill's "Government" article [1820a, p. 39].
} 
economy", the Elements of Political Economy [1821 $]^{34}$, written from his eldest son's - J. S. Mill - school notes, taken during their walks ${ }^{35}$.

The last aspect evoked in the letter concerns J. S. Mill's stay in France ${ }^{36}$. This trip constituted an important step in his education program ${ }^{37}$, which had been rigorously and carefully panned out by his father. J. S. Mill began his trip to France the $20^{\text {th }}$ of May 1820, several days before his fourteenth birthday. He stayed in France for more than a year $^{38}$, since he returned to London in July of $1821^{39}$. J. S. Mill was housed principally at the Bentham residence $-\mathrm{S}$. Bentham ${ }^{40}$, the brother of J. Bentham and his wife M. S. Bentham ${ }^{41}$ - in the south of France, first in Toulouse, then in Montpellier. At the outset of his journey and on his return trip, he benefited from the hospitality of J.-B. Say in Paris $^{42}$. The letter we publish here was written after J. S. Mill's second passage through Paris at the residence of J.-B. Say ${ }^{43}$ from the $23^{\text {rd }}$ of April to the $19^{\text {th }}$ of May 1821, when J. S. Mill was staying with a friend of his father's, Joseph Lowe ${ }^{44}$, in Caen. In this letter, J. Mill thanked J.-B. Say - and his family ${ }^{45}$ - for their hospitality towards his son and expressed his gratitude and desire "to make an adequate return". He guessed that J.-B. Say noticed, in his son, "the defect of which the Benthams have also complained, a

\footnotetext{
${ }^{34}$ The personal library of J.-B. Say having been largely dispersed - on this point, see J.-P. Potier and A. Tiran [2009, p. 159], we do not know whether the Elements figured in his collection. But, to the extent that J. Mill was accustomed, in this period of his life, to sending his works to J.-B. Say, one can presume that he sent him a copy of his textbook as soon as published.

35 J. S. Mill [1873, p. 142].

${ }^{36}$ On this trip, see J. S. Mill [1873, p. 152-154] and J. S. Mill [1820-1821, p. 3-45].

${ }^{37}$ On this program, see J. S. Mill [1873, p. 132-164].

${ }^{38}$ During his trip, J. S. Mill was obliged to keep his father informed by mail regarding the entirety of his intellectual activities. On this point, see J. S. Mill [1820-1821, p. 7].

39 J. S. Mill [1873, p. 154].

${ }^{40} \mathrm{~S}$. Bentham [1757-1831] was an engineer and naval architect. He was also a Brigadier-General in the Russian army. For more information, see M. S. Bentham [1862]. In his autobiography, J. S. Mill [1873, p. 736] wrote that he already knew S. Bentham before his trip to France. He had met him for the first time in 1813 during an excursion in which he had participated with J. Bentham and J. Mill to Oxford, Bath, Bristol, Exeter, Plymouth and Portsmouth.

${ }^{41}$ M. S. Bentham [1765-1858] was the first daughter of George Fordyce [1736-1802], doctor and scientist - he was the author of Traité de la digestion des aliments [1791]. Her interest for science, intellectual curiosity as well as her sense of pedagogy were recognized several times throughout her life. On the influence, in particular, of M. S. Bentham on J. S. Mill, see C. Pease-Watkin [2006].

42 J. S. Mill. [1873, p. 154].

43 J. S. Mill [1820-1821, p. 7-8].

${ }^{44}$ In his biography of J. Mill, A. Bain [1882, p. 80] mentioned that Joseph Lowe was a Scottish statistician.

45 J.-B. Say, his spouse since 1793 , Julie Gournel de Loche, and their five children.
} 
backwardness to mix in conversation", which was, after all, nothing other than the timidity of a child that was precociously experiencing an intense and isolating intellectual education: "I doubt not a considerable remainder of the awkward manners which are the effect of the seclusion in which he had lived". J. Mill ended his letter attributing this timidity, literarily, to "vestiges of hardiness" (vestigia ruris) that should diminish with time, he hoped. This condescending point of view of a father for his son was maintained once J. S. Mill returned to Great Britain ${ }^{46}$. Yet, the manner in which J. S. Mill related his time in France leads us to believe that the trip allowed him not only to develop his literary talent in the composition of a Traité De Logique ${ }^{47}$ in a language he had begun to learn less than a year earlier, but also to open his spirit to the world ${ }^{48}$ and become conscious of the intellectual limits of his family entourage ${ }^{49}$.

We do not know what was in J.-B. Say's response to J. Mill's letter. The only information we dispose is that it was addressed less than three months later, the $6^{\text {th }}$ of September 1821 , by a certain "Clement" ${ }^{50}$. If this delay suggests that the epistolary relationship between J.-B. Say and J. Mill was not necessarily intense, the few letters found to this day - five sum-total - characterizing a relationship that nonetheless lasted more than 10 years $^{51}$, leaves one to imagine the presence of numerous gaps in this correspondence $^{52}$. No major publishing enterprise has yet been undertaken of the correspondence between J.-B. Say and J. Mill: let's hope that that consecrated to J.-B.

\footnotetext{
${ }^{46}$ See, J. Mill to D. Ricardo [23 August 1821, p. 43] et J. S. Mill [1820-1821, p. 11].

${ }^{47}$ One may refer to this Traité in J. S. Mill [1820-1821, p. 11].

48 J. S. Mill [1873, p. 153].

49 Ibid., p. 154.

${ }^{50}$ At the head of the letter from J. Mill, J.-B. Say wrote "Repondu par Clement le 6 septembre 1821" see infra p. 9. It is difficult to identify for sure this mysterious "Clement". It might perhaps be Ambroise Clément [1805-1886], despite his young age in 1821. Future town clerk of Saint-Etienne, and correspondent of the Académie des sciences morales et politiques, this disciple of J.-B. Say edited, in 1854, in the Dictionnaire de l'économie politique the entry on his former mentor. The other hypothesis is that the "Clement" in question is Clement Cornell Biddle [1784-1855], the American editor of the $4^{\text {th }}$ edition of the Traité d'économie politique, from 1821.

${ }^{51}$ Let's remember that the first and last traces of this correspondence date respectively from 20 March 1815 and 28 May 1825.

52 Moreover, the existence of certain unfound letters to this day is detectable from allusions made to them in other letters. See, for example, J. B. Say to J. Bentham [8 July 1820, p. 14].
} 
Say, that will appear in several years within his complete works, will permit to fill in some of these gaps. 


\section{J. Mill to J.-B. Say, $6^{\text {th }}$ of June 1821, Staatsbibliothek zu Berlin. Shelf mark : 2 g 1804 (1)}

[1 r] [Above the date recorded by J. Mill, in Say's handwriting, one can read "James Mill", then, below the date, still in Say's handwriting, "Repondu par Clement le 6 septembre 1821"]

[On the bottom left-hand corner of the folio (location frequently used at the time to designate the addressee of a letter), Mill wrote "M. Jean-Baptiste Say"]

London $6^{\text {th }}$ June 1821

My Dear Sir

I have this morning heard of an opportunity of writing to you, by a gentleman from Scotland ${ }^{53}$, who has a letter to deliver to you at any rate. \& I gladly avail myself of it, to inform you that your letter to $M^{r}$ Prinsep was last night delivered to me by $M^{r} B r o w n^{54}$. I lost no time in perusing it, $\&$ have the satisfaction to say that it appears to me to be admirable ; the matter most important, \& the manner at once pointed \& delicate. I have no doubt [1 v] about the propriety of publishing it. Accordingly I have employed a person to take a copy of it, but shall consult a friend or two who are admirers of yours ${ }^{55}$, before I act upon my own judgement. I shall take care of the translation, I shall procure

\footnotetext{
${ }^{53}$ We have not managed to determine exactly whom they are speaking of here.

${ }^{54}$ It cannot be the Scottish philosopher Thomas Brown, close to the French ideologues and a major influence on the thought of J. Mill: the author of the Inquiry into the relation of cause and effect [1814] had been dead for years. The consultation of the British Biographical Index [2008, vol. 2, p. 596] allows us to propose the name of the librarian and printer, Thomas Brown (1778 ?-1869), who co-published, in 1821, the first English translation of J.-B. Say's Traité. As was his father Christopher, T. Brown was a partner in the Longman Company, a famous London printing house. On the subject of T. Brown and the Longman Company, see respectively F. Boase [1965, p. 439] and J.-D. Mellot \& E. Queval [2004, p. 369].

${ }^{55}$ Among these, J. Mill was perhaps thinking about Francis Place [1771-1854], who, some years later, was given the task of translating, from French to English, several of J.-B. Say's texts. See supra p. 2, n. 9.
} 
the insertion in one of our most respectable journals. It is too long for our newspapers, otherwise I should have been disposed to have it printed in some of them, by which means it would have been more speedily known. I shall endeavour to make some of them notice it, as soon as published.

The praise you bestowed upon the article Government, has emboldened me to beg your acceptance of another article (Jurisprudence) which I have prepared for the same publication. [2 r] My wish has been, in the two taken together, to give a sort of outline of the business of legislation. I have also in hand another work, which if I could hope to execute it properly would, in this country, at least, be of considerable use - I mean a School book of Political Economy ${ }^{56}$. I aim at giving, if I am able, a clear statement of the leading doctrines in their natural $\operatorname{order}^{57} \&$ dependence.

I hope to be able to do so in the compass of an $8^{\text {vo }}$ volume ${ }^{58}, \&$ even a small one. And if it answers my intention it will serve as an introduction to the study of the science, \& will facilitate the perusal of the works which treat of it more profoundly $\&$ in detail.

I have now to return a thousand thanks for the two letters ${ }^{59}$ which I have had the [ $\mathbf{2} \mathbf{v}$ ] pleasure to receive from you. - one extorted from you by my impatience to hear of my son from whom I had a letter ${ }^{60}$ in the same day that yours arrived. For your kindness to him I know not how to thank you. I can hardly forgive myself for putting him in the way of encumbering your family for such a length of time. I can only assure you of our lasting gratitude, \& our desire, if ever it is in our power, to make an adequate return. You have found in him, I perceive, the defect of which the Benthams have also complained, a backwardness to mix in conversation, \& I doubt not a considerable remainder of the

\footnotetext{
${ }^{56}$ Here J. Mill made reference to the Elements of Political Economy.

${ }^{57}$ This terminology is similar to that which Mill [1805, p. 415-416] had used, in the Literary Journal, in his article on Say's Traité: "The object of Say himself is to present a view of the principles of political economy as completely adapted to the wants of the learner as possible; to exhibit them in the most natural and exact order; to explain them in the most simple manner, retrenching every thing but what is necessary to convey a clear idea of the point to be stated $"$.

${ }^{58}$ An edition in- $8^{\circ}$ of the Elements of Political Economy was effectively published in 1821 in London, without an editor's name. An exemplary is conserved at the British Library, under the shelf mark 1027. E. 13.

${ }^{59}$ These two letters have not yet been found.

${ }^{60}$ We were not able to procure this letter for our research.
} 
awkward manners which are the effect of the seclusion in which he had lived. These vestigia ruris will wear out I hope by degrees.

I am, my Dear Sir,

with the greatest esteem

Your most obliged \& faithful

J. Mill 


\section{Bibliography}

Ashbury, D. "Prinsep, Charles Robert", in Donald Rutherford, editor-in-chief, The Biographical Dictionary of British Economists, Bristol: Thoemmes, 2004, vol. 2, p. 980-982.

Bain, A. [1882], James Mill, A Biography, Reprints of Economic Classics, New York: Augustus M. Kelley, 1967.

Bentham, J. The Correspondence of Jeremy Bentham, edition by Stephen Conway, Oxford: Clarendon Press, 1994.

Bentham, J. The Correspondence of Jeremy Bentham, vol. 10, edition by Stephen Conway, Oxford: Clarendon Press, 1994.

Bentham, J. The Correspondence of Jeremy Bentham, vol. 12, edition by Stephen Conway, Oxford: Clarendon Press, 1994.

Bentham, M. S. Life of Brigadier-General Sir Samuel Bentham, London, 1862.

Boase, F. [1965], Modern English Biography, vol. I, A to H, Frank Cass \& co. Ltd.

British biographical index [2008], $3^{\text {rd }}$ cumulated and enlarged edition, vol. 2, München: KG-Saur.

Brown, T. [1814], Inquiry into the relation of cause and effect, fourth edition, London: Henry G. Bown, York street, Covent garden.

Clément, A. [1854], "Jean-Baptiste SAY", Dictionnaire de L'Economie Politique de Charles Coquelin et Gilbert Guillaumin, Paris: Guillaumin.

Darmstaedter Ludwig [1909], Verzeichnis der Autographensammlung - Königliche Bibliothek zu Berlin, Berlin : Stargardt.

Deutsche biographische Enzyklopädie [2005], 2., Überarbeitete und erweiterte Ausgabe, Herausgegeben von Rudolf Vierhaus, München: KG-Saur, vol. 2.

Fordyce, G. [1791], Traité de la digestion des aliments, Londres: in- $8^{\circ}$.

Gehrke, C. \& Kurz, H. D. [2001], "Say and Ricardo on value and distribution", European Journal of the History of Economic Thought, 8 (4), p. 449-486.

Halévy, E. [1901-1904], La formation du radicalisme philosophique, vol. II, Presse Universitaires de France, 1995.

Heertje, A. [1971], "Two Letters from James Mill to Jean-Baptiste Say", History of Political Economy, 3 (2), p. 415-418.

Heertje, A. \& Schoorl. E. [1972], "Jean-Baptiste Say and the education of John Stuart Mill", The Mill Newsletter, 8(1), p. 10-15.

Mellot, J-D. \& Queval, E. [2004], Répertoire d'imprimeurs/libraires (vers 1500-vers 1810), Bibliothèque nationale de France.

Mill, J. [1805], "Say's "Traité"”", The Literary Journal Or Universal Review Of Literature Domestic And Foreign, April, vol. V, p. 412-25.

Mill, J. [1808], Commerce Defended. An Answer to the Arguments by which Mr. Spence, Mr. Cobbett, and Others, have attempted to Prove that Commerce is not a source of National Wealth, London: $\mathrm{C}$. and R. Baldwin, Liberty Fund.

Mill, J. [1820a], "Government", The Supplement of the $4^{\text {th }}, 5^{\text {th }}$ and $6^{\text {th }}$ Editions of The Encyclopaedia Britannica [1824], Edinburg.

Mill, J. [1820b], "Jurisprudence", The Supplement of the $4^{\text {th }}, 5^{\text {th }}$ and $6^{\text {th }}$ Editions of The Encyclopaedia Britannica [1824], Edinburg.

Mill, J. [1821], Elements of Political Economy, Routledge/Thoemmes Press, reprints of the 1844 edition (third edition), 1995.

Mill, J. S. , The Collected Works of John Stuart Mill, J. M. Robson (éd.), University of Toronto Press, 1988.

Mill, J. S. , The Collected Works of John Stuart Mill, vol. I, - Autobiography [1873] and Literary Essay [1824], University of Toronto Press, 1988. 
Mill, J. S. [1820-1821], Journals and Debating Speeches Part I, in The Collected Works of John Stuart Mill, J. M. Robson (éd.), vol. XXVI, 1988.

Pease-Watkin, C. [2006], "The Influence of Mary Bentham on John Stuart Mill", Journal of Bentham Studies 8.

Place, F. [1822], Illustrations and Proofs of the Principle of Population, with introduction and critical and textual notes by Norman E. Himes, London: Geo. Allen and Unwin, 1930.

Potier, J-P. [2009], "Les traducteurs du Traité d'économie politique de Jean-Baptiste Say (1804-1854). Un premier repérage", in Tiran, A. (ed.) Jean-Baptiste Say. Influences, critiques et postérité, Paris: Editions classiques Garnier, p. 131-176.

Potier, J-P. \& Tiran, A. [2009], "L'édition des œuvres complètes de Jean-Baptiste Say", Cahiers d'économie politique, $n^{\circ} 57$, p. 151-173.

Prinsep, C. R. [1816], A Letter of the Earl of Liverpool, on the Cause of the Present Distresses of the Country, and the Efficacy of Reducing the Standard of our Silver Currency, London: printed for Ridgway.

Prinsep, C. R. [1818], An Essay on Money, London: printed for Ridgway.

Ricardo, D. , The Works and Correspondence of David Ricardo, ed. Piero Sraffa with the Collaboration of M.H. Dobb, Indianapolis: Liberty Fund, 2005.

Ricardo, D. , The Works and Correspondence of David Ricardo, ed. Piero Sraffa with the Collaboration of M.H. Dobb, vol. VI, Indianapolis: Liberty Fund, 2005.

Ricardo, D. , The Works and Correspondence of David Ricardo, ed. Piero Sraffa with the Collaboration of M.H. Dobb, vol. VII, Indianapolis: Liberty Fund, 2005.

Ricardo, D. , The Works and Correspondence of David Ricardo, ed. Piero Sraffa with the Collaboration of M.H. Dobb, vol. VIII, Indianapolis: Liberty Fund, 2005.

Ricardo, D. , The Works and Correspondence of David Ricardo, ed. Piero Sraffa with the Collaboration of M.H. Dobb, vol. IX, Indianapolis: Liberty Fund, 2005.

Rieucau, N. [2009], “L'édition d'économistes, quel contenu et quelle forme ?", Cahiers d'économie politique, $\mathrm{n}^{\circ} 57$, p. 7-54.

Say, J.-B. [1803], Traité d'économie politique ou simple exposition de la manière dont se forment, se distribuent ou se consomment les richesses, première édition (1803), Paris: CalmannLévy Editeur, 1972.

Say, J.-B. [1815], De l'Angleterre et des anglais, Paris: Arthus Bertrand, Londres: Berthoud et Weatley.

Say, J.-B. [1821], A Treatise on Political Economy; or The Production, Distribution, and Consumption of Wealth, Translated from the fourth edition of the French (1819) by C. R. Prinsep, with notes by the translator. London: Longman, Hurst, Rees, Orme \& Brown.

Say, J.-B. [1821], A Treatise on Political Economy; or The Production, Distribution, and Consumption of Wealth, Translated from the fourth edition of the French (1819) by C. R. Prinsep, with notes by the translator. Translation of the introduction [Discours préliminaire], and additional notes by C. C. Biddle, Boston: Wells and Lilly.

Say, J.-B. [1824], "Essai historique sur l'origine, les progrès, et les résultats probables de la souveraineté des Anglais en Inde", Extrait de la Revue Encyclopédique, Paris: imprimerie Rignoux.

Say, J.-B. [1833], Mélanges et Correspondances d'Economie Politique, Comte \& Chamerot (ed.).

Say, J.-B. [1840], Cours complet d'économie politique pratique, seconde édition publiée par Horace Say, tome premier, Paris: Guillaumin.

Teilhac, E. [1927], L'œuvre économique de Jean-Baptiste Say, Doctorat de sciences politiques et économiques, Faculté de droit de bordeaux. 
Tiran, A. [1995], J. B. Say, Manuscrits inédits sur la monnaie, la banque et la finance précédé d'un Essai de biographique sur J. B. Say, Numéro spécial hors-série des Cahiers monnaie et finance.

Tiran, A. [2010], études réunies par, Jean-Baptiste Say. Influences, critiques et postérité, Paris: Editions classiques Garnier.

Winch, D. [1966], James Mill: Selected Economic Writings, Edinburgh and London: Oliver Boyd for the Scottish Economic Society.

Wolff, J. [2005], "Jean-Baptiste Say et Napoléon", Revue de I'Institut Napoléon, n¹90, p. 5369.

Yasukawa, R. [1991], "James Mill on Peace and War", Utilitas, 3 (2), p. 179-187.

\section{Correspondence}

Mill, J. to Ricardo, D. , $24^{\text {th }}$ of December 1818, in The Works and Correspondence of David Ricardo, vol. VII, p. 297.

Mill, J. to Ricardo, D. , $14^{\text {th }}$ of January 1819, in The Works and Correspondence of David Ricardo, vol. VIII, p. 10.

Mill, J. to Ricardo, D. , $23^{\text {rd }}$ of August 1821, in The Works and Correspondence of David Ricardo, vol. IX, p. 43.

Mill, J. to Say, J.-B., $25^{\text {th }}$ of February 1817, in Heertje [1971, p. 416-417].

Mill, J. to Say, J.-B., $26^{\text {th }}$ of May 1821, in Heertje, A. \& Schoorl. E. [1972, p. 10-11].

Mill, J. to Say, J.-B., $28^{\text {th }}$ of May 1825, in Heertje, A. [1971, p. 417-418].

J. B. Say to Bentham, J. $8^{\text {th }}$ of July 1820, in The Correspondence of Jeremy Bentham, vol. 10, p. 14.

Say, J.-B. à Prinsep, C. R. , May 1821, in Say, J.-B. [1833, p. 140-141].

\section{Unpublished manuscripts}

Mill, J. to Say, J.-B., $20^{\text {th }}$ of Mars 1815 , Bibliothèque nationale de France, n. a. fr. 26252, f. 264.

Prinsep, C.R. à Say, J.-B., $16^{\text {th }}$ of April 1821, Bibliothèque nationale de France, n. a. fr. 26252, f. 331-333. 